\title{
Variation in pituitary expression of mRNAs encoding the putative inhibin co-receptor (betaglycan) and type-I and type-II activin receptors during the chicken ovulatory cycle
}

\author{
T M Lovell, P G Knight and R T Gladwell \\ School of Animal and Microbial Sciences, The University of Reading, Whiteknights, PO Box 228, Reading, Berkshire RG6 6AJ, UK \\ (Requests for offprints should be addressed to T Lovell; Email: t.m.lovell@reading.ac.uk)
}

\begin{abstract}
Secretion of $\mathrm{LH}$ and FSH from the anterior pituitary is regulated primarily by hypothalamic $\mathrm{GnRH}$ and ovarian steroid hormones. More recent evidence indicates regulatory roles for certain members of the transforming growth factor $\beta$ (TGF $\beta$ ) superfamily including inhibin and activin. The aim of this study was to identify expression of mRNAs encoding key receptors and ligands of the inhibin/activin system in the hen pituitary gland and to monitor their expression throughout the 24-25-h ovulatory cycle. Hens maintained on long days (16 h light/ $8 \mathrm{~h}$ dark) were killed 20,12, 6 and $2 \mathrm{~h}$ before predicted ovulation of a midsequence egg ( $n=8$ per group). Anterior pituitary glands were removed, RNA extracted and cDNA synthesized. Plasma concentrations of LH, FSH, progesterone and inhibin A were measured. Realtime quantitative PCR was used to quantify pituitary expression of mRNAs encoding betaglycan, activin receptor (ActR) subtypes (type I, IIA), GnRH receptor (GnRH-R), LH $\beta$ subunit, FSH $\beta$ subunit and GAPDH. Levels of mRNA for inhibin/activin $\beta A$ and $\beta B$ subunits, inhibin $\alpha$ subunit, follistatin and ActRIIB mRNA in pituitary were undetectable by quantitative PCR ( $<2 \mathrm{amol} /$ reaction). Significant changes in expression
\end{abstract}

$(P<0 \cdot 05)$ of ActRIIA and betaglycan mRNA were found, both peaking $6 \mathrm{~h}$ before ovulation just prior to the preovulatory LH surge and reaching a nadir $2 \mathrm{~h}$ before ovulation, just after the LH surge. There were no significant changes in expression of ActRI mRNA throughout the cycle although values were correlated with mRNA levels for both ActRIIA $(r=0.77 ; P<0 \cdot 001)$ and betaglycan $(r=0 \cdot 45 ; \quad P<0 \cdot 01)$. Expression of GnRH-R mRNA was lowest $20 \mathrm{~h}$ before ovulation and highest $(P<0 \cdot 05) 6 \mathrm{~h}$ before ovulation; values were weakly correlated with betaglycan $(r=0.33 ; P=0.06)$ and ActRIIA $(r=0.34 ; P=0.06)$ mRNA levels. Expression of mRNAs encoding LH $\beta$ and FSH $\beta$ subunit were both lowest $(P<0 \cdot 05)$ after the LH surge, $2 \mathrm{~h}$ before ovulation. These results are consistent with an endocrine, but not a local intrapituitary, role of inhibin-related proteins in modulating gonadotroph function during the ovulatory cycle of the hen, potentially through interaction with betaglycan and ActRIIA. In contrast to mammals, intrapituitary expression of inhibin/activin subunits and follistatin appears to be extremely low or absent in the domestic fowl.

Journal of Endocrinology (2005) 186, 447-455

\section{Introduction}

The regulation of anterior pituitary function is achieved through the balance of central, local and endocrine signals. Gonadotroph cells of the anterior pituitary gland produce both luteinizing hormone (LH) and follicle-stimulating hormone (FSH), which play fundamental roles in the control of ovarian function in the domestic hen. Pituitary gonadotrophin secretion is regulated by the hypothalamic peptide gonadotrophin-releasing hormone $(\mathrm{GnRH}$; also known as LHRH-I; King et al. 1989), acting through GnRH receptors (GnRH-Rs; Millar \& King 1983, Kawashima et al. 1992a). Ovarian steroid-feedback mechanisms also modulate gonadotrophin secretion through both direct and indirect (GnRH-mediated) actions (Luck \& Scanes 1980, King et al. 1989, Kawashima et al. 1992b).

The transforming growth factor $\beta$ (TGF $\beta$ )-superfamily members inhibin and activin are dimeric glycoproteins first identified in gonadal fluids of pigs and cows for their ability to suppress (inhibin) or stimulate (activin) pituitary FSH secretion (de Jong 1988, Ying 1988). The ovary is a major source of inhibin and activin and both molecules have also been implicated as local autocrine/paracrine regulators of folliculogenesis in avian and mammalian species (Findlay 1993, Lovell et al. 2001, 2002a, 2002b, Knight \& Glister 2003). Moreover, in mammals the anterior pituitary is a site of inhibin/activin subunit and follistatin (activin-binding protein) expression and substantive evidence indicates autocrine/paracrine roles for 
these proteins in the regulation of gonadotroph function (see a review by Gregory \& Kaiser 2004). However, the extent to which ligands and receptors of the inhibinactivin-follistatin system are expressed in the avian pituitary gland has not been investigated.

Two forms of inhibin exist, termed inhibin-A and -B; these consist of a common $\alpha$ subunit linked through a disulphide bond to one of two alternative $\beta$ subunits, termed $\beta \mathrm{A}$ and $\beta \mathrm{B}$, respectively. There are three forms of activin, termed activin $\mathrm{A}, \mathrm{B}$ and $\mathrm{AB}$, which are disulphide-linked dimers of two inhibin $\beta$ subunits $(\beta \mathrm{A} \beta \mathrm{A}, \beta \mathrm{B} \beta \mathrm{B}$ and $\beta \mathrm{A} \beta \mathrm{B}$ respectively). Activins signal through interaction with serine/threonine kinase receptors on the cell surface (Ethier \& Findlay 2001). There are two main types of activin receptor, ActRI and ActRII, the latter of which determines ligand-binding specificity. Two ActRII subtypes (A, B) have been cloned in mammalian (Donaldson et al. 1992, Ethier et al. 1994) and avian (Ohuchi et al. 1992, Stern et al. 1995) species and both have a high-affinity binding site for activin. Likewise, ActRI exists as two subtypes (A, B) in mammals (Attisano et al. 1993, Tsuchinda et al. 1995) but only one subtype has so far been identified in birds. Although activin does not bind directly to ActRI (Matsuzaki et al. 1993, ten Dijke et al. 1993), binding of activin to ActRII promotes the formation of a hetero-oligomeric complex of the two receptor types, leading to activation of the activin-induced signalling pathway (Attisano et al. 1993, ten Dijke et al. 1993, Tsuchinda et al. 1993, 1995).

The mechanism of inhibin signal transduction has not been fully elucidated but the favoured model involves inhibin interfering with activin-induced oligomerization of ActRI and ActRII (Gray et al. 2002). In this regard, both ActRII subtypes have been shown to bind inhibin, albeit with low affinity (Mathews and Vale 1991, Attisano et al. 1993). A non-signalling cell-surface molecule termed betaglycan (also known as TGF $\beta$ type-III receptor) also binds inhibin-A with high affinity. Moreover, binding to betaglycan increases the affinity of inhibin-A for ActRII, rendering inhibin-A more effective at blocking activininduced oligomerization of ActRI and ActRII (Lewis et al. 2000, Matzuk 2000). Thus, betaglycan is considered to be an important co-receptor for inhibin.

The objectives of the present study were firstly to determine whether betaglycan, activin receptor subtypes (ActRI, IIA and IIB) and inhibin-related proteins (inhibin/activin $\alpha, \beta \mathrm{A}$ and $\beta \mathrm{B}$ subunits and follistatin) are expressed in the hen pituitary gland and secondly to quantify mRNA expression levels throughout the hen ovulatory cycle in order gain an insight into potential endocrine and/or local intrapituitary roles of these proteins in the avian reproductive system. To help achieve this we also quantified expression of mRNAs for GnRH-R, LH $\beta$ subunit and FSH $\beta$ subunit in the same pituitary glands and plasma samples were analysed for LH, FSH, inhibin-A and progesterone.

\section{Materials and Methods}

\section{Experimental animals}

Laying hens (Goldline) towards the end of the first year of lay, with a clutch average of at least five eggs, were caged individually and maintained under a standard long-day photo-schedule of $16 \mathrm{~h}$ of light and $8 \mathrm{~h}$ of darkness, at an ambient temperature of $21-23^{\circ} \mathrm{C}$. Food and water were freely available. Ovipositions were recorded using timelapse recording technology and used to predict the time of ovulation.

\section{Recovery of pituitary glands, RNA purification and cDNA synthesis}

Hens ( $n=8$ per group) were killed by cervical dislocation $4,12,18$ and $22 \mathrm{~h}$ after predicted ovulation of a midsequence egg. Pituitary glands were dissected, weighed and homogenized in a 15-times volume of Tri-reagent (Sigma) using an Ultra-Turrax T8 homogenizer (IKA, Staufen, Germany). RNA was subsequently purified as described in the standard Tri-reagent protocol. The final RNA pellet was resuspended in $100 \mu \mathrm{l}$ nuclease-free water (containing RNA Secure; Ambion), and then treated with RNase-free DNase (15 min at $37^{\circ} \mathrm{C}$; RQ1; Promega). The purified RNA was re-purified using a 15-times volume of Tri-reagent. The resultant purified RNA was resuspended in $50 \mu \mathrm{l}$ nuclease-free water (containing RNA Secure).

RNA was then quantified on a spectrophotometer (GeneQuant; GE Healthcare). cDNA was synthesized using ImProm-II reverse transcriptase (using protocol and buffers provided; Promega), $1 \mu \mathrm{g}$ RNA, $0.5 \mu \mathrm{g}$ random hexamer primers (MWG-Biotech), dNTPs (0.5 mM final; Promega) and $0.5 \mu \mathrm{l}$ RNase inhibitor (40 U/ $\mu \mathrm{l}$; Ambion). cDNA synthesis was terminated by heat-inactivation $\left(15 \mathrm{~min}\right.$ at $\left.70^{\circ} \mathrm{C}\right)$. cDNA samples were treated with $1 \mu \mathrm{l}$ RNase cocktail $(0.5 \mathrm{U} / \mu \mathrm{l}$ RNase A and $20 \mathrm{U} / \mu \mathrm{l}$ RNase

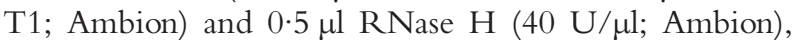
which specifically degrades the RNA in RNA-DNA hybrids. A $1 \mu \mathrm{l}$ aliquot of cDNA was removed for estimation using a fluorometric assay (Oligreen ssDNA quantification assay; Molecular Probes).

Blood samples were collected prior to cervical dislocation into heparinized tubes, centrifuged at $3000 \mathrm{~g}$ for 20 min at $4{ }^{\circ} \mathrm{C}$ and the plasma was stored at $-20{ }^{\circ} \mathrm{C}$ until required.

\section{Recovery of positive control ovarian tissue, RNA purification and $c \mathrm{DNA}$ synthesis}

Hens $(n=4)$ were killed by cervical dislocation $12 \mathrm{~h}$ after predicted ovulation of a midsequence egg. The F4-F6 follicles were dissected into granulosa and theca layers and combined as separate pools. Tissue pools were weighed, 
Table 1 TaqMan primer and probe sequences used in this study

\begin{tabular}{|c|c|c|c|c|}
\hline & $\begin{array}{l}\text { Forward primer } \\
\left(5^{\prime} \text { to } 3^{\prime}\right)\end{array}$ & $\begin{array}{l}\text { Reverse primer } \\
\left(5^{\prime} \text { to } 3^{\prime}\right)\end{array}$ & $\begin{array}{l}\text { TaqMan probe } 5^{\prime} \text { [6-FAM] } \\
\text { to } 3^{\prime} \text { [TAMRA] }\end{array}$ & Accession number \\
\hline \multicolumn{5}{|l|}{ Target } \\
\hline ActRI & ccggaggtcttggacgaaа & gcccagatatcgaccctcttg & catccaggcagactgcttcgactcc & AJ318064 \\
\hline ActRIIB & tccctgcttaacatcctggtgta & ccaagaggatggccactga & tctctgctgccatcgctgtcct & U31223 \\
\hline Betaglycan & atgaagcttgcacctctctgaat & gacaagaggcttggtgaaggttt & tggatatgatcttggccatgatgcaca & L01121 \\
\hline GnRH-R & acctcggccactcactgc & cacctttgctgcttttgtgaac & tggagcactgggtcgagcсcC & NM204653 \\
\hline Inhibin $\alpha$ subunit & gggctgggacaattggat & actactgccacgggaactgtg & tgcaccccagcagcttcgttttc & U48438 \\
\hline Inhibin $\beta A$ subunit & caccatccgcctgtttcaac & cctccatatcttctgctccttca & cagcggcagccgaaaggca & U26946 \\
\hline Inhibin $\beta B$ subunit & ttttagtggtgcaagccg & aagaggcctggagtgcgat & ctcgctgataacaaacacaggatccgg & AF055478 \\
\hline Follistatin subunit & tgtgctccggattgctctaa & tcctgtaggtttcccatctaagc & atcacttggaagggccccgtgtg & NM205200 \\
\hline GAPDH & ggagtcaacggatttggcc & tttgccagagaggacggc & tattggccgcctggtcaccagg & K01458 \\
\hline
\end{tabular}

6-FAM, 6-carboxyfluorescein; TAMRA, carboxytetramethylrhodamine.

extracted and cDNA was prepared as described above. The granulosa tissue from F4-F6 preovulatory follicles have previously been demonstrated to express mRNA for follistatin, inhibin/activin $\beta \mathrm{A}$ and $\beta \mathrm{B}$ subunits and inhibin $\alpha$ subunit (Davis \& Johnson 1998).

\section{Quantitative PCR (Q-PCR)}

Duplicate Q-PCR reactions were carried out using $1 \mu \mathrm{l}$ diluted reverse transcriptase reaction mixture or $1 \mu \mathrm{l}$ standard (for 200-1.56 amol/ $\mu \mathrm{l}$ ), in a volume of $25 \mu \mathrm{l}$ containing $13.5 \mu \mathrm{l}$ master $\operatorname{mix}(\mathrm{Ab}$ gene), $2 \mu \mathrm{l}$ forward primer, $2 \mu \mathrm{l}$ reverse primer, $1 \mu \mathrm{l}$ probe (see Table 1 for probe and primer sequences) and $5.5 \mu \mathrm{l}$ nuclease-free water. The samples were processed for 40 PCR cycles using an ABI Prism 7700 sequence detector (Applied Biosystems, Warrington, Cheshire, UK) with the following thermal cycler conditions: stage $1,50{ }^{\circ} \mathrm{C}$ for $2 \mathrm{~min}$; stage $2,95^{\circ} \mathrm{C}$ for $15 \mathrm{~min}$; stage 3,40 cycles of $95^{\circ} \mathrm{C}$ for $15 \mathrm{~s}$ and $60{ }^{\circ} \mathrm{C}$ for $1 \mathrm{~min}$. TaqMan primers and probes were designed to target mRNA sequence based on criteria set by Applied Biosystems.

\section{Immunoassays}

Plasma concentrations of inhibin-A were determined using a two-site ELISA, LH and FSH were measured by RIA and progesterone by competitive ELISA as described previously (Follett et al. 1972, Krishnan et al. 1993, Lovell et al. 2000, 2001). Within- and between-assay coefficients of variation for each assay were less than $10 \%$.

\section{Statistical analysis}

One-way ANOVA was used in conjunction with post-hoc Fisher's protected least significant difference (PLSD) test to determine whether concentrations of hormones and expression of mRNAs encoding receptors and gonadotrophin subunits varied at different time points. Levels of expression of each mRNA detected, including GAPDH mRNA, was normalized to total cDNA. GAPDH mRNA expression normalized in this way did not vary across the cycle. $P<0.05$ was considered to be significant. Unless otherwise stated, values are means \pm S.E.M. $(n=8)$. Ovulatory cycle data are expressed relative to the predicted time of ovulation.

\section{Results}

Plasma inhibin-A, LH, FSH and progesterone during the hen ovulatory cycle

Plasma concentrations of inhibin-A, progesterone, LH and FSH were determined to verify the correct timing of pituitary collection relative to predicted time of ovulation. As shown in Fig. 1 the changes in plasma LH and progesterone observed were consistent with the wellestablished preovulatory peak in plasma LH and progesterone $\sim 4$ h before ovulation (Etches \& Cunningham 1976). Likewise, as reported previously (Lovell et al. 2000), plasma inhibin-A also showed a significant $(P<0 \cdot 05)$ pattern of change throughout the ovulatory cycle, whereas FSH concentrations did not vary significantly.

Pituitary expression of $m R N A$ for betaglycan and activin receptor subtypes (types $I, I I A$ and IIB) during the hen ovulatory cycle

Changes in pituitary expression of mRNAs encoding betaglycan, ActRI and ActRIIA during the hen ovulatory cycle are shown in Fig. 2. Concentrations of ActRIIA mRNA peaked at $6 \mathrm{~h}$ prior to the expected time of ovulation (around the onset of LH surge) at 


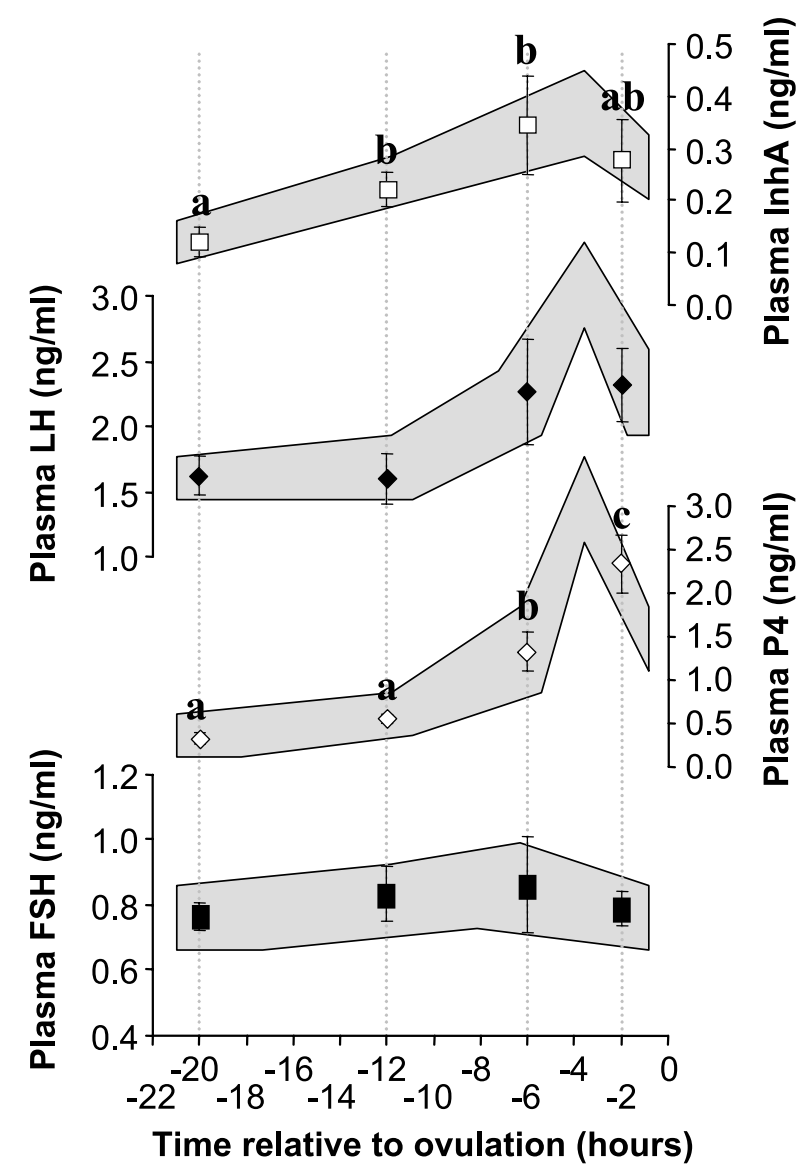

Figure 1 Plasma concentrations of inhibin-A (InhA), progesterone (P4), $\mathrm{LH}$ and $\mathrm{FSH}$ determined at four time points during the ovulatory cycle of the domestic hen. Values are means \pm S.E.M. $(n=8$ per time point) and means without a common letter are significantly different $(P<0 \cdot 05 ;$ ANOVA and Fisher's PLSD test). For comparison the shaded areas show typical hormone profiles (mean \pm S.E.M.) in hens blood-sampled longitudinally throughout the ovulatory cycle (Lovell et al. 2000).

$20 \cdot 7 \mathrm{amol} / \mu \mathrm{g}$ cDNA. Levels fell significantly $(P<0 \cdot 05)$ to a post-LH surge nadir $(9.3 \mathrm{amol} / \mu \mathrm{g} \mathrm{cDNA})$, approximately $2 \mathrm{~h}$ before ovulation. At 20 and $12 \mathrm{~h}$ before ovulation ActRIIA mRNA levels were not significantly different from those $2 \mathrm{~h}$ prior to ovulation. ActRI mRNA levels were positively correlated with ActRIIA mRNA levels $(r=0 \cdot 77 ; P<0 \cdot 001)$ but the changes during the cycle did not reach statistical significance. Betaglycan mRNA expression, like ActRI and ActRIIA, was greatest before the onset of the preovulatory $\mathrm{LH} /$ progesterone surge, with levels falling significantly $(P<0 \cdot 05)$ from 6 to $2 \mathrm{~h}$ prior to ovulation (range, 1.0-0.67 amol/ $\mu \mathrm{g}$ cDNA). Betaglycan mRNA levels were positively correlated with both ActRI $(r=0 \cdot 45 ; P<0 \cdot 01)$ and ActRIIA $(r=0 \cdot 39 ; P<0 \cdot 05)$ mRNA levels. ActRIIB expression was below the detection limit of the Q-PCR procedure (2 amol/reaction) at all stages of the ovulatory cycle.

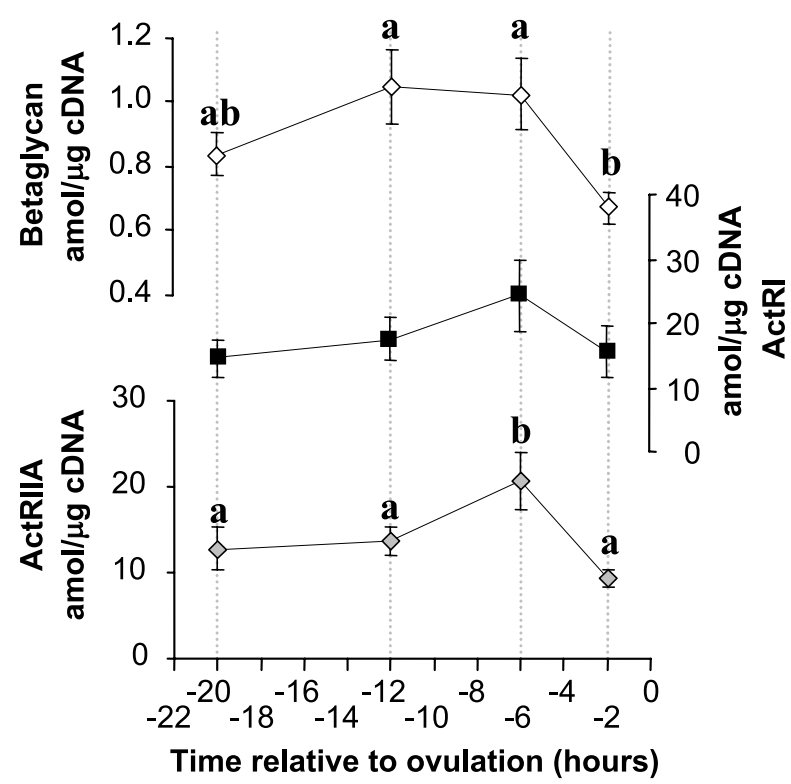

Figure 2 Expression of mRNA for betaglycan, ActRI and ActRIIA in the pituitary gland of laying hens at four time points during the ovulatory cycle. Values are means \pm S.E.M. $(n=8$ per time point) and means without a common letter are significantly different $(P<0 \cdot 05$; ANOVA and Fisher's PLSD test). mRNA levels are normalized to total cDNA.

Pituitary expression of $m R N A$ for $G n R H-R, L H \beta$ subunit and FSH $\beta$ subunit during the hen ovulatory cycle

Pituitary expression of mRNAs encoding GnRH-R, LH $\beta$ subunit and FSH $\beta$ subunit during the hen ovulatory cycle are shown in Fig. 3. Expression of GnRH-R mRNA was lowest $20 \mathrm{~h}$ before ovulation $(8.5 \mathrm{amol} / \mu \mathrm{g}$ cDNA). Expression increased $(P<0 \cdot 05)$ from 20 to $12 \mathrm{~h}$ before ovulation to a maximal value some 3 -fold higher at $6 \mathrm{~h}$ before ovulation $(29.8 \mathrm{amol} / \mu \mathrm{g} \mathrm{cDNA})$, before tending to fall (37\%; not significant) after the LH surge. Levels of mRNA for FSH $\beta$ subunit and LH $\beta$ subunit were highest at 20 and $12 \mathrm{~h}$ before expected ovulation and at their lowest values $(P<0 \cdot 05)$ after the preovulatory $\mathrm{LH}$ surge, some $2 \mathrm{~h}$ before expected ovulation. There was a significant correlation between mRNA levels for the two gonadotrophin subunits $(r=0 \cdot 45 ; P<0 \cdot 01)$.

Pituitary expression of $m R N A$ s for inhibin/activin $\alpha, \beta A$ and $\beta B$ subunits and follistatin during the hen ovulatory cycle

Levels of pituitary expression of mRNAs encoding inhibin/activin $\alpha, \beta A$ and $\beta B$ subunit and follistatin were consistently below the detection limit of the Q-PCR procedure $(<2 \mathrm{amol} /$ reaction $)$ at all stages of the ovulatory cycle. Positive control samples from hen follicular granulosa and theca tissue processed and analysed in the same manner had readily measurable amounts of these mRNA transcripts (see Table 2). 


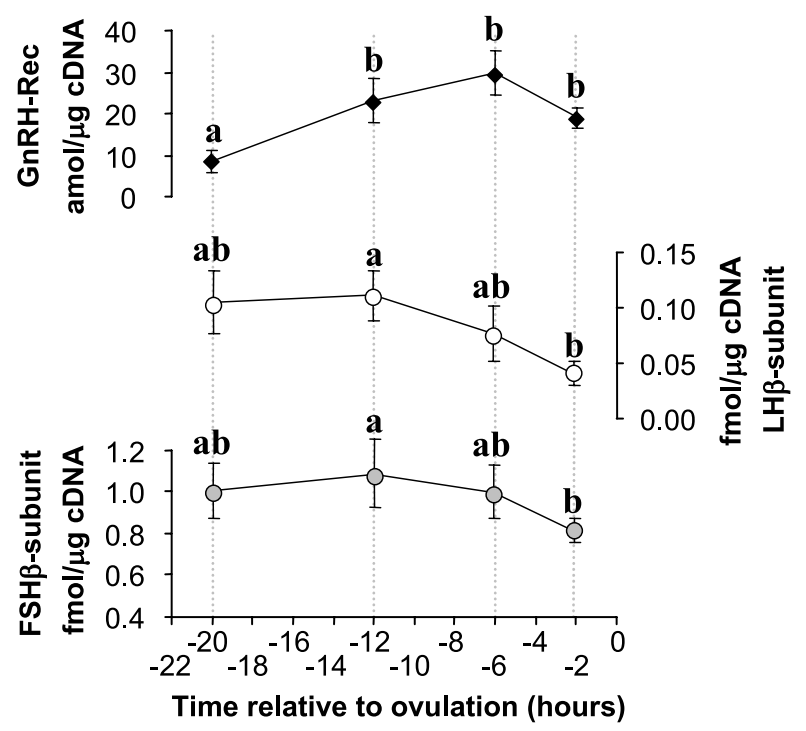

Figure 3 Expression of mRNA for LH $\beta$, FSH $\beta$ and GnRH-R in the pituitary gland of laying hens at four time points during the ovulatory cycle. Values are means \pm S.E.M. ( $n=8$ per time point) and means without a common letter are significantly different $(P<0 \cdot 05$; ANOVA and Fisher's PLSD test). mRNA levels are normalized to total cDNA.

Pituitary expression of GAPDH $m R N A$ during the hen ovulatory cycle

There were no significant differences $(P>0 \cdot 05)$ in pituitary expression of GAPDH mRNA across the hen ovulatory cycle (range, $0.43 \pm 0.4-0.50 \pm 0.07 \mathrm{fmol} / \mu \mathrm{g}$ cDNA).

\section{Discussion}

Inhibin, activin and follistatin were initially identified in mammals as gonadally derived proteins capable of modu-

Table 2 RNA transcripts detected in the hen pituitary gland by TaqMan quantitative PCR; F4-F6 granulosa and theca tissue were analysed as positive controls

\begin{tabular}{|c|c|c|c|}
\hline & $\begin{array}{l}\text { Pituitary } \\
\text { gland }\end{array}$ & $\begin{array}{l}\text { F4-F6 } \\
\text { granulosa }\end{array}$ & $\begin{array}{l}\text { F4-F6 } \\
\text { theca }\end{array}$ \\
\hline \multicolumn{4}{|l|}{ RNA transcript } \\
\hline Betaglycan & + & + & + \\
\hline ActRI & + & + & + \\
\hline ActRIIA & + & + & + \\
\hline ActRIIB & - & + & + \\
\hline Inhibin $\alpha$ subunit & - & + & + \\
\hline Inhibin $\beta A$ subunit & - & + & + \\
\hline Inhibin $\beta B$ subunit & - & + & + \\
\hline Follistatin & - & + & + \\
\hline GnRH-R & + & nd & nd \\
\hline LH $\beta$ subunit & + & nd & nd \\
\hline FSH $\beta$ subunit & + & nd & nd \\
\hline
\end{tabular}

+ , detectable; - , undetectable; nd, not determined. lating pituitary FSH secretion (Ying 1988). Subsequently it was discovered that activin and follistatin are also expressed in the mammalian anterior pituitary where they act as local modulators of gonadotroph function, including regulation of GnRH-R and FSH $\beta$ subunit expression (DePaolo et al. 1991, Marshall et al. 1997). The avian ovary, like its mammalian counterpart, expresses inhibin, activin and follistatin (Davis \& Johnson 1998, Knight et al. 2005), but it has not been determined whether an endogenous pituitary inhibin-activin-follistatin system exists in birds. Likewise, there is no information on expression of ActRs in the avian pituitary, although one recent study (Sweeney \& Johnson 2005) confirmed that the inhibin coreceptor betaglycan is expressed in hen anterior pituitary.

Here we used quantitative reverse transcription PCR (Taqman) to examine mRNA expression of ActR subtypes (types I, IIA and IIB), betaglycan and inhibin-related proteins (follistatin and inhibin/activin $\alpha, \beta \mathrm{A}$ and $\beta \mathrm{B}$ subunits) in the hen anterior pituitary and to monitor their levels throughout the ovulatory cycle. For positive control purposes we also evaluated expression of all eight mRNA transcripts in pooled extracts of hen ovarian theca and granulosa. Pituitary expression of GnRH-R was also investigated as activin has been shown to increase pituitary GnRH-R expression in rats (Braden \& Conn 1992) and thereby affect FSH and LH secretion (Liu et al. 1995). GnRH-R mRNA levels was highest prior to the onset of the LH surge, as also demonstrated in the ewe (Brooks et al. 1993). This also accords with a study on Japanese quail showing that pituitary responsiveness to chicken GnRH-I was greater before the preovulatory LH surge than at any other time of the cycle (Connolly \& Callard 1988). We also monitored expression of LH $\beta$ and FSH $\beta$ subunits to help interpret our findings in relation to gonadotrophin synthesis and plasma gonadotrophin levels during the cycle. Pituitary expression of LH $\beta$ and FSH $\beta$ subunits were both lowest after the preovulatory LH/ progesterone surge about $2 \mathrm{~h}$ before ovulation, presumably reflecting transient desensitization of gonadotrophs to the stimulatory effect of $\mathrm{GnRH}$. The disparity between mRNA and plasma FSH profiles may be due to the processes of translation, post-translational modification and dimerization between the $\alpha$ and specific $\beta$ subunit to form FSH prior to secretion by the pituitary gland.

Our results showed readily detectable expression of mRNA for betaglycan, ActRI and ActRIIA, GnRH-R, LH $\beta$ and FSH $\beta$ in hen anterior pituitary, consistent with this tissue as being a target site for inhibin/activin action. Ligand-induced association of type I and type II ActRs is required to mediate the biological response to activin (Carcamo et al. 1994) and so the presence of ActRI and ActRIIA in hen pituitary (and ovary) is compatible with activin responsiveness. Inhibin signalling is believed to involve binding of inhibin to betaglycan which, in turn, enhances the affinity of inhibin for the type II activin receptor making it a more effective activin antagonist 
(Phillips \& Woodruff 2004). Thus, our finding of betaglycan expression in both hen pituitary and ovary, which concurs with the recent report of Sweeney \& Johnson (2005), is compatible with inhibin responsiveness.

Despite the use of sensitive Taqman assays, we were unable to detect expression of mRNA for inhibin $\alpha$ subunit, inhibin/activin $\beta A$ and $\beta B$ subunit, follistatin or ActRIIB in hen pituitary tissue even though each of these transcripts was readily detected in hen ovarian tissue samples. Hecht et al. (2000) and Davis \& Johnson (1998) were also unable to detect inhibin/activin $\beta B$ and follistatin mRNA expression in the laying-hen pituitary by Northern blot hybridization; however, they were able to detect expression in all extragonadal tissues analysed using Southern blotting of PCR-amplified cDNA. Expression of inhibin/activin $\beta B$ and follistatin mRNA has been well documented in mammalian anterior pituitary tissue; several studies have also detected lower levels of expression of inhibin $\alpha$ and $\beta$ A subunit mRNA (Meunier et al. 1988, Marshall et al. 1997, Dalkin et al. 1998). In addition, pituitary follistatin mRNA level varies markedly during the rat oestrous cycle (Halvorson et al. 1994); mRNAs for inhibin/activin subunits are relatively uniform across the cycle (Halvorson et al. 1994). Thus it appears that, unlike mammals, the avian anterior pituitary lacks the capacity for endogenous production of inhibins (A, B), activins (A, B, $A B)$ or follistatin. Alternatively, the relevant mRNAs may be expressed at such low levels in the laying hen as to be undetectable by quantitative reverse transcription PCR. Either way, our findings imply that there is little or no autocrine/paracrine regulation of gonadotrophin production by endogenous (pituitary-derived) inhibin, activin or follistatin in the hen, in marked contrast to mammalian species examined so far. Since the present observations are confined to adult laying hens (Gallus domesticus) it would be unwise to excluded the possibility that birds in other physiological states (e.g. sexually immature, ovariectomized), male birds or other avian species do not exhibit significant pituitary expression of inhibin-related proteins. In this regard, gonadectomy in rats results in enhanced pituitary expression of inhibin/activin subunit and follistatin mRNA (Marshall et al. 1997).

Regarding the changes we observed during the hen ovulation cycle, levels of ActRIIA and betaglycan mRNA were significantly higher before the preovulatory LH/ progesterone surge ( $6 \mathrm{~h}$ before ovulation), as compared with after the $\mathrm{LH} /$ progesterone surge some $2 \mathrm{~h}$ before ovulation. While ActRI expression did not vary significantly across the ovulatory cycle, values were positively correlated with ActRIIA and betaglycan mRNA levels. As mentioned above, ActRIIB expression was below the detection limit throughout. Differential pituitary expression of ActR subtypes has been reported in other (mammalian) species including sheep and rat. For instance, in the ewe pituitary gland ActRIA, ActRIB, ActRIIA, ActRIIB and betaglycan were all detectable through- out the ovulatory cycle (Fafioffe et al. 2004). Levels of ActRIA, ActRIB and ActRIIB mRNA were significantly higher before the preovulatory surge and during the secondary surge of FSH as compared with during the preovulatory surge and the luteal phase. Levels of ActRIIA and betaglycan mRNA did not vary throughout the sheep oestrous cycle. Likewise in the rat pituitary expression of betaglycan mRNA did not fluctuate across the rat oestrous cycle (Bernard \& Woodruff 2001). However, a subsequent immunolocalization study revealed that the amount of betaglycan protein on the surface of gonadotrophs does vary, being highly correlated with the inverse changes in serum inhibin and FSH levels around the time of the secondary FSH surge (Chapman \& Woodruff 2003). Interaction between circulating inhibin and local (pituitary-derived) activin-B probably plays a key role in the generation of the secondary FSH surge which occurs independently of LH release and initiates follicular recruitment during the rat oestrous cycle. The observation (Corrigan et al. 1991) that in vitro immunoneutralization of endogenous activin-B increased FSH secretion by isolated rat pituitary cells reinforces this concept. Also, mice lacking inhibin have elevated activin and FSH levels (Matzuk et al. 1992, 1994) while mice lacking activin receptor type II receptor have suppressed FSH levels (Matzuk et al. 1995). Although the present study did not attempt to study the anatomical distribution of mRNA transcripts or their corresponding protein products in hen pituitary, Sweeney \& Johnson (2005) recently showed by immunohistochemistry that there is strong colocalisation of betaglycan with FSH-containing cells in the hen pituitary, again supporting a functional role for inhibin in FSH regulation.

As with activin, other ligands of the TGF $\beta$ superfamily bind to and form a hetero-oligomeric complex with two types of cell-surface receptor, designated types I and II. However, not all types I and II receptor associations elicit a cellular response (Attisano et al. 1993, ten Dijke et al. 1994a, 1994b). Through interaction with betaglycan, inhibin could also disrupt the interaction of type II receptors with other members of the TGF $\beta$ superfamily, such as the bone morphogenic proteins (Cook et al. 2004). However, the significance of this required further evaluation. There also is the possibility that other members of the TGF $\beta$ superfamily may play an important role in the regulation of pituitary gonadotroph function in the hen. For example, TGF $\beta$ can modulate the association of inhibin with betaglycan, with TGF $\beta 2$ being a more effective competitor than TGF $\beta 1$ for binding of inhibin-A to L $\beta$ T2 cells (Ethier et al. 2002). Indeed, it has been shown that TGF $\beta$ can rescue the activin A-induced promoter activity when inhibin-A is present. The physiological significance of this finding in the hen pituitary is as-yet unknown, but a similar role could occur as TGF $\beta$ expression has been demonstrated in the chicken anterior pituitary (Chowdhury et al. 2003). 
During ovarian preovulatory follicle development in the laying hen, inhibin-A is produced selectively by granulosa cells of the largest follicle (F1) of the preovulatory hierarchy (Lovell et al. 1998, 2000, 2001, 2003). Correspondingly, plasma inhibin-A levels vary in a cyclic manner during the hen ovulatory cycle (Lovell et al. 2000). Despite this, plasma FSH concentrations (Lovell et al. 2000) and pituitary FSH $\beta$ subunit expression (this study) do not vary significantly during the ovulatory cycle. This contrasts with the dynamic changes in pituitary FSH secretion observed during the oestrous cycle in mammals and suggests a different functional relationship between inhibin-related proteins and FSH in chickens compared with mammals. Avian ovarian cycles do not have the equivalent of a luteal phase, as follicles are developing in what could be termed 'constant follicular phase', with hens ovulating and laying an egg approximately every $24-25 \mathrm{~h}$. In the laying hen regular recruitment of a 'selected' ovarian follicle from the pool of pre-hierarchical follicles occurs despite a uniform level of circulating FSH. Variability in FSH-responsiveness is thought to explain how a single follicle is recruited to the preovulatory hierarchy each cycle (Tilly et al. 1991, Johnson et al. 2004, Knight et al. 2005). This is in contrast to mammals where interplay between endogenous pituitary activin and follistatin, and ovary-derived inhibin, acutely regulates FSH $\beta$ subunit expression leading to transient peaks in plasma FSH and the FSH-dependent recruitment of a cohort of follicles, one or more of which may subsequently be selected for ovulation (Besecke et al. 1997, Gajewska et al. 2002, Webb et al. 2003).

In conclusion, the present study has shown that the putative inhibin co-receptor betaglycan and type I and IIA ActRs are expressed in the anterior pituitary gland of the domestic hen consistent with this tissue being a target of inhibin/activin action. The apparent absence of endogenous pituitary expression of inhibin/activin $\alpha, \beta \mathrm{A}$ and $\beta \mathrm{B}$ subunits and follistatin in the hen stands in marked contrast to mammalian species in which an intrapituitary activinfollistatin system plays a prominent role in the regulation of gonadotroph function.

\section{Acknowledgements}

We thank Mr SA Feist for skilled technical assistance, Dr J Proudman for FSH assay reagents and the BBSRC for financial support (grant 45/S17120). The authors declare that there is no conflict of interest that would prejudice the impartiality of this scientific work.

\section{References}

Attisano L, Carcamo J, Ventura F, Weis FMB, Massague J \& Wrana JL 1993 Identification of human activin and TGF $\beta$ type I receptors that form heteromeric kinase complexes with type II receptors. Cell 75 671-680.
Bernard DJ \& Woodruff TK 2001 Inhibin binding protein in rats: alternative transcripts and regulation in the pituitary across the estrous cycle Molecular Endocrinology 15 654-667.

Besecke LM, Guendner MJ, Sluss PA, Polak AG, Woodruff TK, Jameson JL, Bauer-Dantoin AC \& Weiss J 1997 Pituitary follistatin regulates activin-mediated production of follicle-stimulating hormone during the rat estrous cycle. Endocrinology 138 2841-2848.

Braden TD \& Conn PM 1992 Activin-A stimulates the synthesis of gonadotropin-releasing hormone receptors. Endocrinology 130 2101-2105.

Brooks J, Taylor PL, Saunders PT, Eidne KA, Struthers WJ \& McNeilly AS 1993 Cloning and sequencing of the sheep pituitary gonadotrophin-releasing hormone receptor and changes in expression of its mRNA during the estrus cycle. Molecular and Cellular Endocrinology 94 R23-R27.

Carcamo J, Weis FM, Ventura F, Wieser R, Wrana JL, Attisano L \& Massague J 1994 Type-I receptors specify growth-inhibitory and transcriptional responses to transforming growth factor $\beta$ and activin. Molecular and Cellular Biology 14 3810-3821.

Chapman SC \& Woodruff TK 2003 Betaglycan localization in the female rat pituitary: implications for the regulation of follicle-stimulating hormone by inhibin. Endocrinology 144 5640-5649.

Chowdhury VS, Nishibori M \& Yoshimura Y 2003 Changes in the expression of TGFbeta-isoforms in the anterior pituitary during withdrawal and resumption of feeding in hens. General and Comparative Endocrinology 133 1-7.

Connolly PB \& Callard IP 1988 Changes in pituitary responsiveness during the ovulatory cycle of the Japanese quail, in vitro. Journal of Experimental Zoology 247 172-176.

Cook RW, Thompson TB, Jardetzky TS \& Woodruff TK 2004 Molecular biology of inhibin actions. Seminars in Reproductive Medicine 22 269-276.

Corrigan AZ, Bilezikjian LM, Carroll RS, Bald LN, Schmelzer CH, Fendly BM, Mason AJ, Chin WW, Schwall RH \& Vale W 1991 Evidence for an autocrine role of activin $\mathrm{B}$ within rat anterior pituitary cultures. Endocrinology 128 1682-1684.

Dalkin AC, Haisenleder DJ, Gilrain JT, Aylor K, Yasin M \& Marshall JC 1998 Regulation of pituitary follistatin and inhibin/activin subunit messenger ribonucleic acids (mRNAs) in male and female rats: evidence for inhibin regulation of follistatin mRNA in females. Endocrinology $1392818-2823$.

Davis AJ \& Johnson PA 1998 Expression pattern of messenger ribonucleic acid for follistatin and the inhibin/activin subunits during follicular and testicular development in Gallus domesticus. Biology of Reproduction 59 271-277.

DePaolo LV, Bicsak TA, Erickson GF, Shimasaki S \& Ling N 1991 Follistatin and activin: a potential intrinsic regulatory system within diverse tissues. Proceedings of the Society for Experimental Biology and Medicine 198 500-512.

ten Dijke P, Ichijo H, Franzen P, Schulz P, Saras J, Toyoshima H, Heldin CH \& Miyazono K 1993 Activin receptor-like kinases: a novel subclass of cell surface receptors with predicted serine/threonine kinase activity. Oncogene 8 2879-2887.

ten Dijke P, Yamashita H, Ichijo H, Franzen P, Laiho M, Miyazono K \& Heldin CH 1994a Characterization of type I receptors for transforming growth factor- $\beta$ and activin. Science 264 101-104.

ten Dijke P, Yamashita H, Sampath TK, Reddi AH, Estevez M, Riddle DL, Ichijo H, Heldin CH \& Miyazono K $1994 b$ Identification of type-I receptors for osteogenic protein-1 and bone morphogenetic protein-4. Journal of Biological Chemistry 269 16985-16988.

Donaldson CJ, Mathews LS \& Vale WW 1992 Molecular cloning and binding properties of the human type-II activin receptor. Biochemical and Biophysical Research Communications 184 310-316.

Etches RJ \& Cunningham FJ 1976 The interrelationship between progesterone and luteinizing hormone during the ovulation cycle of the hen (Gallus domesticus). Journal of Endocrinology 71 51-58. 
Ethier JF \& Findlay JK 2001 Roles of activin and its signal transduction mechanisms in reproductive tissues. Reproduction 121 $667-675$.

Ethier JF, Houde A, Lussier JG \& Silversides DW 1994 Bovine activin receptor type II cDNA: cloning and tissue expression. Molecular and Cellular Endocrinology 106 1-8.

Ethier JF, Farnworth PG, Findlay JK \& Ooi GT 2002 Transforming growth factor- $\beta$ modulates inhibin A bioactivity in the L $\beta$ T2 gonadotrope cell line by competing for binding to betaglycan. Molecular Endocrinology 16 2754-2763.

Fafioffe A, Ethier JF, Fontaine J, Jean-Pierre E, Raragnat C \& Dupont J 2004 Activin and inhibin receptor gene expression in the ewe pituitary throughout the oestrous cycle. Journal of Endocrinology 182 $55-68$.

Findlay JK 1993 An update on the roles of inhibin, activin, and follistatin as local regulators of folliculogenesis. Biology of Reproduction 48 15-23.

Follett BK, Scanes CG \& Cunningham FJ 1972 A radioimmunoassay for avian luteinizing hormone. Journal of Endocrinology 52 359-378.

Gajewska A, Siawrys G, Bogacka I, Przala J, Lerrant Y, Counis R \& Kochman K 2002 In vivo modulation of follicle-stimulating hormone release and beta subunit gene expression by activin A and the GnRH agonist buserelin in female rats. Brain Research Bulletin 58 475-480

Gray PC, Bilezikjian LM \& Vale W 2002 Antagonism of activin by inhibin and inhibin receptors: a functional role of betaglycan. Molecular and Cellular Endocrinology 188 254-260.

Gregory SJ \& Kaiser UB 2004 Regulation of gonadotropins by inhibin and activin. Seminars in Reproductive Medicine 22 253-267.

Halvorson LM, Weiss J, Bauer-Dantoin AC \& Jameson JL 1994 Dynamic regulation of pituitary follistatin messenger ribonucleic acids during the rat estrous cycle Endocrinology 134 1247-1253.

Hecht DJ, Davis AJ, Brooks CF \& Johnson PA 2000 Molecular cloning and expression analysis of the complementary deoxyribonucleic acid for chicken inhibin/activin $\beta \mathrm{B}$ subunit Biology of Reproduction 62 1128-1134.

Johnson AL, Bridgham JT \& Woods DC 2004 Cellular mechanisms and modulation of activin A- and transforming growth factor beta-mediated differentiation in cultured hen granulosa cells. Biology of Reproduction 71 1884-1851.

de Jong FH 1988 Inhibin. Physiological Reviews 68 555-607.

Kawashima M, Takeo H, Kamiyoshi M \& Tanaka K 1992a Luteinizing hormone-releasing hormone receptor bindings of the hen pituitary: difference between laying and nonlaying hens, effects of ovarian steroid hormones in vivo, and changes during an ovulatory cycle. Poultry Science 71 1079-1086.

Kawashima M, Ukai A, Kamiyoshi M, \& Tanaka K $1992 b$ Effect of progesterone in vitro on luteinizing hormone production in hen pituitary cells pretreated with estrogen. Poultry Science $\mathbf{7 1}$ $1215-1220$.

King JA, Davidson JS, Mehl AEI, Wakefield IK, Andersson PB \& Millar RP 1989 Gonadal steroid modulation of signal transduction and luteinizing hormone release in cultured chicken pituitary cells. Endocrinology 124 1830-1840.

Knight PG \& Glister C 2003 Local roles of TGF $\beta$ superfamily members in the control of ovarian follicle development. Animal Reproduction Science 78 165-183.

Knight PG, Gladwell RT \& Lovell TM 2005 The inhibin-activin system and ovarian folliculogenesis in the chicken. In: Functional Avian Endocrinology pp 323-337, Eds A Dawson \& P J Sharp. New Delhi: Narosa Publishing House.

Krishnan KA, Proudman JA, Bolt DJ \& Bahr JM 1993 Development of an homologous radioimmunoassay for chicken follicle-stimulating hormone and measurement of plasma FSH during the ovulatory cycle. Comparative Biochemistry and Physiology A: Comparative Physiology 105 729-734.
Lewis KA, Gray PC, Blount AL, MacConell LA, Wiater E, Bilezikjian LM \& Vale W 2000 Betaglycan binds inhibin and can mediate functional antagonism of activin signalling. Nature $\mathbf{4 0 4}$ 411-414.

Liu RC, Lea RW \& Sharp PJ 1995 Sexually differentiated role of calcium ions in chicken GnRH-I-stimulated release of LH from anterior pituitary glands from adult domestic chickens. General and Comparative Endocrinology 100 267-272.

Lovell TM, Gladwell RT, Cunningham FJ, Groome NP \& Knight PG 1998 Differential changes in inhibin A, activin A, and total $\alpha$-subunit levels in granulosa and thecal layers of developing preovulatory follicles in the chicken. Endocrinology 139 1164-1171.

Lovell TM, Vanmontfort D, Bruggeman V, Decuypere E, Groome NP, Knight PG \& Gladwell RT 2000 Circulating concentrations of inhibin-related proteins during the ovulatory cycle of the domestic fowl (Gallus domesticus) and after induced cessation of egg laying. Journal of Reproduction and Fertility 119 323-328.

Lovell TM, Knight PG, Groome NP \& Gladwell RT 2001 Changes in plasma inhibin A levels during sexual maturation in the female chicken and the effects of active immunization against inhibin $\alpha$-subunit on reproductive hormone profiles and ovarian function. Biology of Reproduction 64 188-196.

Lovell TM, Gladwell RT, Groome NP \& Knight PG 2002a Modulatory effects of gonadotrophins and insulin-like growth factor on the secretion of inhibin A and progesterone by granulosa cells from chicken preovulatory (F1-F3) follicles. Reproduction 123 291-300.

Lovell TM, Gladwell RT, Groome NP \& Knight PG $2002 b$ Activin exerts differential effects on basal and gonadotrophin-induced secretion of inhibin A and progesterone by granulosa cells from chicken preovulatory (F1-F3) follicles. Reproduction 124 649-657.

Lovell TM, Gladwell RT, Groome NP \& Knight PG 2003 Ovarian follicle development in the laying hen is accompanied by divergent changes in inhibin A, inhibin B, activin A and follistatin production in granulosa and theca layers. Journal of Endocrinology 177 45-55.

Luck MR \& Scanes CG 1980 Ionic and endocrine factors influencing the secretion of luteinizing hormone by chicken anterior pituitary cells in vitro. General and Comparative Endocrinology 41 260-265.

Marshall JC, Dalkin AC, Haisenleder DJ \& Kirk SE 1997 Inhibins, activins, follistatin, and GnRH: Regulators of gonadotropin subunit gene expression. In Inhibin, Activin and Follistatin. Regulatory Functions in System and Cell Biology, Serono Symposia, pp 39-50. Eds T Aono, H Sugino \& WW Vale. New York: Springer.

Matzuk MM 2000 In search of binding- Identification of inhibin receptors. Endocrinology 141 2281-2284.

Matzuk MM, Finegold MJ, Su JGJ, Hsueh AJW \& Bradley A 1992 $\alpha$-Inhibin is a tumour-suppressor gene with gonadal specificity in mice. Nature $360313-319$.

Matzuk MM, Finegold MJ, Mather JP, Krummen L, Lu H \& Bradley A 1994 Development of cancer cachexia-like syndrome and adrenal tumors in inhibin-deficient mice. PNAS 91 8817-8821.

Matzuk MM, Kumar TR \& Bradley A 1995 Different phenotypes for mice deficient in either activins or activin receptor type II. Nature 374 356-360

Mathews LS \& Vale WW 1991 Expression cloning of an activin receptor, a predicted transmembrane serine kinase. Cell $\mathbf{6 5}$ 973-982.

Matsuzaki K, Xu JM, Wang F, McKeehan WL, Krummen L \& Kan M 1993 A widely expressed transmembrane serine/threonine kinase that does not bind activin, inhibin, transforming growth factor $\beta$, or bone morphogenic factor. Journal of Biological Chemistry 268 12719-12723.

Meunier H, Rivier C, Evans RM \& Vale W 1988 Gonadal and extragonadal expression of inhibin $\alpha, \beta \mathrm{A}$, and $\beta \mathrm{B}$ subunits in various tissues predicts diverse functions. PNAS 85 247-251.

Millar RP \& King JA 1983 Synthesis, luteinizing hormone-releasing activity, and receptor binding of chicken hypothalamic luteinizing hormone-releasing hormone. Endocrinology 113 1364-1369. 
Noce T, Ando H, Ueda T, Kubokawa K, Higashinakagawa T \& Ishii S 1989 Molecular cloning and nucleotide sequence analysis of the putative cDNA for the precursor molecule of the chicken LH- $\beta$ subunit. Journal of Molecular Endocrinology 3 129-137.

Ohuchi H, Noji S, Koyama E, Myokai F, Nishikawa K, Nohno T, Tashiro K, Shiokawa K, Matsuo N \& Taniguchi S 1992 Expression pattern of the activin receptor type IIA gene during differentiation of chick neural tissues, muscle and skin. FEBS Letters 303 185-189.

Phillips DJ \& Woodruff TK 2004 Inhibin: actions and signalling. Growth Factors 22 13-18.

Stern CD, Yu RT, Kakizuka A, Kintner CR, Mathews LS, Vale WW, Evans RM \& Umesono K 1995 Activin and its receptors during gastrulation and the later phases of mesoderm development in the chicken embryo. Developmental Biology 172 192-205.

Sweeney SA \& Johnson PA 2005 Messenger RNA and protein expession analysis of betaglycan in the pituitary and ovary of the domestic hen. Biology of Reproduction 72 172-178.

Tilly JL, Kowalski KI \& Johnson AL 1991 Stage of ovarian follicular development associated with the initiation of steroidogenic competence in avian granulosa cells. Biology of Reproduction $\mathbf{4 4}$ 305-314.
Tsuchida K, Mathews LS \& Vale WW 1993 Cloning and characterization of a transmembrane serine kinase that acts as an activin type-I receptor. PNAS 90 11242-11246.

Tsuchida K, Vaughan JM, Wiater E, Gaddy-Kurten D \& Vale WW 1995 Inactivation of activin-dependent transcription by kinase-deficient activin receptors. Endocrinology 136 5493-5503.

Webb R, Nicholas B, Gong JG, Campbell BK, Gutierrez CG, Garverick HA \& Armstrong DG 2003 Mechanisms regulating follicular development and selection of the dominant follicle. Reproduction Supplement 61 71-90.

Ying SY 1988 Inhibins, activins, and follistatins: gonadal proteins modulating the secretion of follicle-stimulating hormone. Endocrine Reviews 9 267-293.

Received in final form 17 June 2005

Accepted 24 June 2005

Made available online as an Accepted Preprint

30 June 2005 